SVU- International Journal of Veterinary Sciences, 3 (1): 80-86, 2020.

Print ISSN: 2535-1826

Online ISSN: 2535-1877

CrossMark

Research Article

Open Access

\title{
Toxic effects of formalin on the medical students of South Valley University following repeated exposure at the anatomy laboratories
}

\author{
Yasser Ahmed ${ }^{1 *}$, Mohammed Abdelsabour-Khalaf ${ }^{2}$, Eman Abdelrahim $^{3}$, Ahmed Ghallab ${ }^{4,5}$
}

${ }^{1}$ Department of Histology, Faculty of Veterinary Medicine, South Valley University, Qena, Egypt; ${ }^{2}$ Department of Anatomy and Embryology, Faculty of Veterinary Medicine, South Valley University, Qena, Egypt; ${ }^{3}$ Deaprtment of Histology, Faculty of Medicine, South Valley University, Qena, Egypt; ${ }^{4}$ Department of Forensic Medicine and Toxicology, Faculty of Veterinary Medicine, South Valley University, Qena, Egypt; ${ }^{5}$ Leibniz Research Centre for Working Environment and Human Factors at the Technical University Dortmund, Dortmund, Germany.

\section{Abstract}

Formalin is widely used in the anatomy dissecting rooms to preserve the animal cadavers and biological specimens in veterinary medical schools. Veterinary medical students at South Valley University are routinely exposed to formalin during their practical training. Although formalin is known to cause severe health problems, the toxic effects of formalin on the veterinary students at South Valley University has not been investigated before. Thus, the current study aimed to explore the toxic effects of exposure of veterinary medical students to formalin in the anatomy laboratories and to suggest some preventive measures to reduce its toxic effects. For this purpose, a total number of 167 students from the first- and the second-year at the department of anatomy, Faculty of Veterinary Medicine, South Valley University were surveyed. Approximately $79.6 \%$ of the students suffered from unpleasant smell, followed by eye irritation (63.6\%), nasal irritation (51.5\%), headache (44.9\%), breathing difficulties (39.5), visual disturbance (29.5), lack of concentration $(26.9 \%)$, cough $(25.1 \%)$, lethargy and fatigue $(19.2 \%)$, nausea $(18 \%)$, digestive disturbance (14.4\%), sore throat and dryness (12\%), sleep disturbance (4.8\%) and fainting (6\%). In conclusion, the present study demonstrates that the Veterinary Medical students are at risk of severe health problems due to prolonged exposure to formalin in the anatomy dissecting rooms. This calls The South Valley University authorities to apply a guideline to reduce the effect of exposure to formaldehyde in the anatomy laboratories.

Keywords: Formalin; Formaldehyde; Anatomy; Veterinary students; SVU.

DOI: $10.21608 / \mathrm{svu} .2020 .24069 .1042$

Received: February 15, 2020

Accepted: March 14, 2020

Published: March 14, 2020

*Corresponding Author:Prof. Yasser A. Ahmed

E-mail: yasser.ali@vet.svu.edu.eg

Citation: Ahmed et al., 2020, Toxic effects of formalin on the medical students of South Valley University following repeated exposure at the anatomy laboratories. SVU-IJVS 2020, 3(1): 80-86.

Copyright: () Ahmed. This is an open access article distributed under the terms of the creative common attribution license, which permits unrestricted use, distribution and reproduction in any medium provided the original author and source are created.

Competing interest: The authors have declared that no competing interest exists.

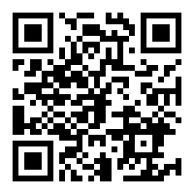




\section{Introduction}

Formalin is the aqueous solution of formaldehyde (Jain et al., 2012). It is widely used as a preservative and disinfectant. Concentrations of a 37-50 \% are routinely used in the anatomy laboratories to preserve cadavers and biological specimens. Formaldehyde is a colourless flammable gas at room temperature with a pungent odour. It reaches the body either through inhalation, ingestion or skin contact (Wilbur et al., 1999). After absorption, formaldehyde is usually metabolized by liver and other tissues into a non-toxic metabolite known as formate which excreted through the urine or converted to carbon dioxide and excreted through the exhalation (Inci et al., 2013).

The exposure to formaldehyde vapors with a high dose results in many health problems. such as altered immunity (Thrasher et al., 1987), respiratory dysfunction (Khaliq and Tripathi, 2009; Chukwudi et al., 2018), hypogonadism and testicular damage (Ihim Augustine Chinedu et al., 2017), increased serum urea, uric acid, total protein and albumin (Chinedu et al., 2017), damage to nasal mucosal epithelium (Pinheiro et al., 2016) or altered immunity. Furthermore, formaldehyde was described as a human carcinogen (Program, 2011). The increased concentration of the formaldehyde in the dissecting rooms is due to using a high concentration of formalin, poor working practice leading to leakage the solution out of the practice area or cadavers, or due to the poor ventilation. Students, workers and staff of the anatomy department are commonly exposed to formaldehyde toxicity during embalming animal cadavers and practical teaching classes.

Due to the nature toxicity of formaldehyde, the National Institute of Occupational Safety and Health (NIOSH) presented its permissible exposure limit of $0.1 \mathrm{ppm}$ for a short period does not exceed 15 minutes (Zhang et al., 2009). However, in the anatomy laboratories of the Faculty of Veterinary medicine, South Valley university, no monitoring of the formaldehyde concentration in the air are applied. Many students were discomfort with the anatomy lessons due to exposure to formalin. The present study was undertaken to highlight the clinical symptoms of formalin toxicity on the undergraduates after formaldehyde exposure in anatomy dissecting rooms.

\section{Materials and Methods \\ Questionnaire design}

The current study was a crosssectional study conducted in the Departments of Anatomy, Faculty of Veterinary Medicine, South Valley University, Egypt. The study protocol was approved by the institutional ethical committee of South Valley University. A total number of 167 from the first and the second-year students who are routinely exposed to formalin in their anatomy course, were included in the present study. The questionnaire of this study includes three parts: the first part is about the demographic profile for the students (age, sex, height, and weight). The second part seeks information about their awareness of the harmful effect of formalin (e.g. if they get trained to protect themselves from these effects and the frequency, and duration of formalin exposure. The third part explores the clinical symptoms they feel following exposure to formalin in the dissecting anatomy rooms.

\section{Statistical Analysis}

The questionnaire was analyzed using EXCELL 2016. The results were expressed as Mean \pm standard error (SE). 


\section{Results}

The demographic data of the students included in the study were described in Table 1.

Table 1: Student's demographic data

\begin{tabular}{|l|l|}
\hline Age (Years); mean \pm SE & $18.5 \pm 0.1$ \\
\hline $\begin{array}{l}\text { Length (centimetres); mean } \pm \\
\text { SE }\end{array}$ & $164 \pm 1.6$ \\
\hline Weight $(\mathrm{kg}) ;$ mean $\pm \mathrm{SE}$ & $64 \pm 1.1$ \\
\hline $\begin{array}{l}\text { Smoking student } \\
\text { (percentage) }\end{array}$ & $0 \%$ \\
\hline $\begin{array}{l}\text { Male students (number) } \\
\text { Female students (number) }\end{array}$ & $\begin{array}{l}\mathrm{n}=51 \\
\mathrm{n}=96\end{array}$ \\
\hline $\begin{array}{l}1^{\text {st }} \text { year students (number) } \\
2^{\text {nd }} \text { year students (number) }\end{array}$ & $\mathrm{n}=105$ \\
& $\mathrm{n}=62$ \\
\hline
\end{tabular}

The analysis of the questionnaire revealed that out of the surveyed students, approximately $85 \%$ were aware that exposure to formalin could cause a health problem, 21 students $(12.6 \%)$ were not sure and only 4 students $(2.4 \%)$ were not expecting that exposure to formalin could harm their health. Most of the students (approximately 96.5\%) responded that they were not introduced to a training or information session to protect themselves when exposed to formalin in the anatomy dissecting rooms, and 51 students $(30.5 \%)$ declared that they had this training sessions. Most of the students, approximately $73 \%$, were exposed to formalin via both the skin intact and inhalation routes, and approximately $27 \%$ were exposed via the inhalation route only. Regarding the frequency of exposure, most of the students (approximately $61 \%$ ) were exposed to formalin only once a week. The daily exposure time to formalin varied. Approximately $49 \%$ of the students were exposed to formalin for 1-2 hours/day, about $44 \%$ were exposed for 35 hours/day, and exposure more than 5 hours/day was rare (1.2\%). In addition, repeated exposure for 2-3 times or more than 3 times was also reported in 36.5 and $3 \%$, respectively. To protect themselves from the toxic effects of formalin, the students used to wear protective coats $(93.4 \%)$, gloves $(77.2 \%)$, googles $(1.2 \%)$ and none of the students used the protective shoes. Regarding the symptoms of formalin exposure, all of the surveyed students showed signs of intoxication ranging from mild local irritation of the contact membrane, to severe systemic effects including bronchial asthma and digestive disturbances. The toxic effects of the formalin exposure were summarized in Table 2.

Table 2: The effects of formalin exposure on the veterinary medical students at south valley university.

\begin{tabular}{|c|c|c|}
\hline Symptoms & $\begin{array}{c}\text { No. of } \\
\text { affected } \\
\text { student } \\
\text { out of } \\
167\end{array}$ & $\begin{array}{c}\text { Percentage } \\
(\%)\end{array}$ \\
\hline Unpleasant smell & 133 & 79.6 \\
\hline $\begin{array}{c}\text { Eye irritation and } \\
\text { excess lacrimation }\end{array}$ & 106 & 63.5 \\
\hline $\begin{array}{c}\text { Nasal irritation, } \\
\text { tingling sensation and } \\
\text { running or congested } \\
\text { nose }\end{array}$ & 86 & 51.5 \\
\hline Headache & 75 & 44.9 \\
\hline Breathing difficulties & 66 & 39.5 \\
\hline Visual disturbance & 50 & 29.5 \\
\hline Lack of concentration & 45 & 26.9 \\
\hline Cough & 42 & 25.1 \\
\hline $\begin{array}{c}\text { Tiredness and } \\
\text { dizziness }\end{array}$ & 33 & 19.8 \\
\hline $\begin{array}{c}\text { Skin problem such as } \\
\text { Itching, sore skin on } \\
\text { hands, burning } \\
\text { sensation }\end{array}$ & 32 & 19.2 \\
\hline Nausea & 30 & 18 \\
\hline Digestive disturbance & 24 & 14.4 \\
\hline $\begin{array}{c}\text { Sore throat and } \\
\text { dryness }\end{array}$ & 20 & 12 \\
\hline Sleep disturbance & 8 & 4.8 \\
\hline Fainting & 6 & 3.6 \\
\hline
\end{tabular}




\section{Discussion}

Formaldehyde is a flammable colourless gas at room temperature. Formalin is the aqous form of formaldehyde and is routinely used as a preservative for animal cadavers and biological specimens in anatomy laboratories . Hence, veterinary medical students are routinely exposed to formalin in the anatomy dissections rooms. The present study aimed to explore the toxic effects of formalin on the first- and second-year students of the Faculty of Veterinary Medicine at South Valley University (SVU), Egypt. A cohort of 167 students were included in the study and reported the clinical symptoms appeared after their exposure to formalin vapour in the anatomy dissecting room. The students were exposed to formaldehyde, at least, 1 hour in a day/week. The main route of exposure is the direct contact during animal's cadavers examination, or through inhalation of formalin vapour in the air. Most of the students were aware that formalin could cause health problems, but they were not introduced to training or information sessions to learn how they protect themselves. Nevertheless, most of them used coats and gloves only to protect themselves during classes.

After exposure to formalin, the students at the SVU reported that they suffered from unpleasant smell, eye irritation, excessive lacrimation, nose irritation, congesting and running nose, headache, breathing difficulties, visual disturbance, lack of concentration, cough, tiredness and dizziness, skin problems, nausea, digestive disturbance, sore throat and irritation, sleep disturbance and fainting. Similar symptoms were reported on medical students of different schools worldwide after exposure to formalin in anatomy dissecting rooms. The includes the students of the Dr. Vaishampayan

Memorial Govt Medical College in India (Jain et al., 2012); the students of Himalayan Institute of Medical Sciences, Dehradun, India (Dhar and Chaudhuri, 2019); the students of Medical College, Raigarh in India (Kundu and Gangrade, 2015); the MBBS students in Srinagar, Jammu and Kashmir (Nisa et al., 2016) and in Bundelkhand, Sagar, India (Yadav and Yadav, 2014); the students of the Little Flower Institute of Medical Sciences and Research, Angamaly in India (Roy et al., 2015); the medical students at L N Medical College and Research center, Bhopal, India (Nair et al., 2016); the medical students at Niger Delta University, Nigeria (Onyije and Avwioro, 2012); the students of the College of Health Sciences, Nnamdi Azikiwe University in Nigeria (Chinedu et al., 2017; Ihim Augustine Chinedu et al., 2017; Chukwudi et al., 2018).

The exact mechanism of formalininduced toxicity is not fully understood. Some studies reported that it acts mainly by local irritation of the contact membranes due to its high reactivity characters with free thiol and amine groups of cellular proteins and DNA (Feron et al., 1991; Conaway et al., 1996; Moran, 2001; Doty et al., 2004) (Moran et al., 2001; Conaway et al., 1996). Once absorbed, formalin is rapidly metabolized via formaldehyde dehydrogenase enzyme, mainly in the liver and erythrocytes, into formic acid. Although this is an inactivate metabolism, as formic acid is ultimately metabolized into carbon dioxide and water, the excessive formation of formic acid might disturb the acid-base balance leading to metabolic disorders (Eells et al., 1981). Although the toxic effects of formalin are mainly due to acute exposure, carcinogenic 
potential was also reported following chronic exposure to formalin (Coggon et al., 2003).

In conclusion, the Veterinary Medical students at the SVU are at risk of severe health problems due to the routine exposure to formalin in the anatomy dissecting rooms. The present study provides a piece of extra evidence and supports the previous studies that call the authorities to pay a special care about the hazardous effects of repeated exposure to formalin in the anatomy laboratories of the medical students.

\section{Recommendations}

To reduce the toxic effect of exposure to formalin, we recommend the following actions: (1) The awareness of the students about the toxic effect of formalin should be raised; (2) The students should be encouraged to use protective equipments and clothing such as coats, gloves, goggles, shoes, and masks; (3) The ventilation of the anatomy laboratories should be improved; (4) the spillage of the formalin should be minimized, and continuous flashing of the animal cadavers with freshwater during examination and removal of the dipping formalin from the tray should be applied; (5) arterial injection of formalin should be followed instead of embedding the whole animal cadavers in formalin; (6) the formaldehyde concentration in the air should be continuously monitored and must not exceed the international permissible limits; and (7) the authorities at the SVU should seek alternative less hazardous chemicals to preserve animal cadavers in Anatomy rooms.

\section{Compliance with Ethical Standards}

Funding (Optional): The current study was funded by a grant from the South Valley University in 2019.
Conflict of Interest: No conflict of interest is required by the authors.

Ethical approval: The study protocol was approved by the institutional ethical committee of South Valley University.

\section{Acknowledgement}

The current study was funded by a grant from the South Valley University in 2019.

\section{References}

Chinedu IA, Chukwuemeka OE, Nwabunwanne OV, Ndumnworo ODF, Chidiebere OE, Igube NA, Kalu AU, Emmanuel AB. 2017. Effect of Short-Term Exposure to Formalin on Kidney Function Tests of Students In Nnewi. European Journal of Biomedical 4:51-55.

Chukwudi O, Stephen M, Stephen M, Victor O. 2018. Effects of formaldehyde inhalation on cardiopulmonary functions on medical students of college of health sciences nnamdi azikiwe university during dissection classes. A J Physiol Biochem Pharmacol American Journal of Physiology, Biochemistry and Pharmacology 7:86.

Coggon D, Harris EC, Poole J, Palmer KT. 2003. Extended follow-up of a cohort of British chemical workers exposed to formaldehyde. Journal of the National Cancer Institute 95:1608-1615.

Conaway CC, Whysner J, Verna LK, Williams GM. 1996. Formaldehyde mechanistic data and risk assessment: endogenous protection from DNA adduct formation. Pharmacology \& therapeutics 71:29-55. 
Dhar DK, Chaudhuri S. 2019. A Study To Assess Acute Physical Reactions Expesure To Formalderienced By First Year Medical Students On Expohyde During Gross Anatomy Dissection. Indian Journal Of Applied Research 9 (1): 18-19.

Doty RL, Cometto-Muniz JE, Jalowayski AA, Dalton P, Kendal-Reed M, Hodgson M. 2004. Assessment of upper respiratory tract and ocular irritative effects of volatile chemicals in humans. Critical reviews in toxicology 34:85-142.

Eells JT, McMartin KE, Black K, Virayotha V, Tisdell RH, Tephly TR. 1981. Formaldehyde poisoning: rapid metabolism to formic acid. Jama 246:1237-1238.

Feron V, Til H, De Vrijer F, Woutersen R, Cassee F, Van Bladeren P. 1991. Aldehydes: occurrence, carcinogenic potential, mechanism of action and risk assessment. Mutation Research/Genetic Toxicology 259:363-385.

Ihim Augustine Chinedu, Ogbodo Emmanuel Chukwuemeka, Ozuruoke Donatus Francis Ndumnworo, Amah Ubuo Kalu, Oguaka Victor Nwabunwanne, Igube NA. 2017. Effect of ShortTerm Exposure to Formalin on Male Reproductive Hormones of Students in Nnewi. IOSR Journal of Dental and Medical Sciences (IOSR-JDMS) 16:33-36.

Inci M, Zararsiz I, Davarci M, Gorur S. 2013. Toxic effects of formaldehyde on the urinary system. Turk J Urol 39:48-52.

Jain S, Nahar P, Baig M. 2012. Study of formalin toxicity in I MBBS students. Cough 3:233-235.

Khaliq F, Tripathi P. 2009. Acute effects of formalin on pulmonary functions in gross anatomy laboratory. Indian J Physiol Pharmacol 53:93-96.

Kundu S, Gangrade P. 2015. Study of the toxic effects of formaldehyde vapours within dissection hall on the first year Indian medical students. Int J Anat Res 3:11791190.

Moran L. 2001. Gutteridge JM, Quinlan GJ. Thiols in cellular redox signalling and control Curr Med Chem 8:763-772.

Nair SK, Thaduri N, Joshi RV, Gupta SD. 2016. An exploration of hazardous effects of formaldehyde fumes on medical students. International Journal of Biomedical and Advance Research 7:485-488.

Nisa G, Ahmad Shah B, Shahdad PS, Jan N, Samoon S, Ahmad S. 2016. Acute Toxic Effects of Formalin on First Year MBBS Students during Dissection In Gross Anatomy Laboratory. IOSR Journal of Dental and Medical Sciences 15:56-59.

Onyije FM, Avwioro OG. 2012. Excruciating effect of formaldehyde exposure to students in gross anatomy dissection laboratory. Int $\mathrm{J}$ Occup Environ Med 3:92-95.

Pinheiro LCP, Nascimento HMS, Menegardo CS, Silva RG, Lorenzoni DC, Souza LNdGd. 2016. Nuclear alterations in nasal mucosa epithelial cells of students exposed to formaldehyde. Med segur trab 62:4-14.

Program NT. 2011. Report on carcinogens. In, 12th edition ed. Research Triangle Park: U.S. Dept. of Health and Human Services, Public Health Service.

Roy PP, Sailesh KS, Padmanabha, Mishra S, Antony NJ. 2015. Effects of Exposure to Formaldehyde in 
Anatomy Dissection Hall. Res J Pharm Biol Che 6:1602-1604.

Thrasher JD, Wojdani A, Cheung G, Heuser G. 1987. Evidence for formaldehyde antibodies and altered cellular immunity in subjects exposed to formaldehyde in mobile homes. Arch Environ Health 42:347-350.

Wilbur SB, Harris MO, McClure PR, Spoo W. 1999. Toxicological profile for formaldehyde.
Yadav A, Yadav M. 2014. A Study of the Effects of Formalin on First Year MBBS Students

Scholars Journal of Applied Medical Sciences (SJAMS) 2:1588-1590.

Zhang L, Steinmaus C, Eastmond DA, Xin XK, Smith MT. 2009. Formaldehyde exposure and leukemia: a new meta-analysis and potential mechanisms. Mutation Research/Reviews in Mutation Research 681:150-168. 